\title{
Somatostatin Binding Capacity, Guanylate Cyclase and Tyrosine Phosphatase Activities During Pancreatic Proliferation in the Rat Induced by Gastrectomy
}

\author{
E. RODRÍGUEZ-MARTÍN,* A. M. VALENCIA** B. COLÁS,* C. GARCÍA-ESCRIBANO, $\dagger$ \\ M. RODRÍGUEZ-PUYOL, $\dagger$ C. SUSINI $\ddagger$ AND E. ARILLA*।
}

*Unidad de Neuroendocrinología Molecular, Departamento de Bioquímica y Biología Molecular and †Departamento de Fisiología y Farmacología, Facultad de Medicina, Universidad de Alcalá de Henares, E-28871 Alcalá de Henares, Madrid, Spain and łInstitut National de la Santé et de la Recherche Médicale U 151, CHU Rangueil, Toulouse, France

Received 22 March 1995

\begin{abstract}
RODRÍGUEZ-MARTÍN, E., A. M. VALENCIA, B. COLÁS, C. GARCÍA-ESCRIBANO, M. RODRÍGUEZ-PUYOL, C. SUSINI AND E. ARILLA. Somatostatin hinding capacity, guanylate cyclase and tyrosine phosphatase activities during pancreatic proliferation in the rat induced by gastrectomy. PEPTIDES 16(8) 1461-1467, 1995.-Gastrectomy increased pancreatic growth and this effect was associated with an increase in the number of somatostatin-14 (SS) receptors (146\% of control) without altering their affinity. SS incrcased guanylate cyclase activity twofold in pancreatic acinar membranes from gastrectomized rats. The gastrectomy decreased pancreatic SS-like immunoreactivity (SS-LI) content (55\% of control levels) and tyrosine phosphatase activity ( $74 \%$ of control levels). Administration of proglumide ( $20 \mathrm{mg} / \mathrm{kg}, \mathrm{IP})$, a gastrin/cholecystokinin (CCK) receptor antagonist, suppressed the inhibitory effect of gastrectomy on basal tyrosine phosphatase activity and SS-LI content, which returned to control levels. Furthermore, proglumide suppressed the increase of the number of SS receptors and of SS-stimulated guanylate cyclase activity induced by gastrectomy. All this suggests that pancreatic acinar cell growth is associated with upregulation of SS receptors, which could represent a mechanism promoted by the cell to negatively regulate the mitogenic activity of pancreatic growth factors such as CCK. In addition, the results also suggest that the negative regulation of tyrosine phosphatase activity may be important in the events involved in the pancreatic hyperplasia observed after gastrectomy.
\end{abstract}

$\begin{array}{lll}\text { Gastrectomy } & \text { Guanylate cyclase } & \text { Somatostatin receptors } \\ \text { Somatostatin like-immunoreactivity } & \text { Pancreatic acinar membranes }\end{array}$

SOMATOSTATIN-14 (SS) is a tetradecapeptide synthesized in endocrine $D$ cells that is widely distributed in the gastrointestinal tract $(4,21)$ and is known to inhibit the stimulatory effects of various secretagogues on a number of cell functions, including endocrine and exocrine functions of the pancreas (53). More recently, SS analogues have been shown to inhibit the growth of normal and tumoral cells $(23,45)$. In the pancreas, SS inhibited normal $(23,45)$ and caerulein-stimulated pancreatic growth $(31,42)$, whereas the neutralization of the endogenous SS with antiserum amplified the growth-stimulating effect of caerulein (31). These observations have led to the suggestion that this peptide has a physiologically important function in the regulation of normal cell growth and that it might be a negative regulator of pancreatic acinar cell proliferation in vivo. SS exerts its physiological actions by interacting with membrane-bound receptors
$(48,58)$, which are coupled to adenylate cyclase $(43), \mathrm{K}^{+}$channels (61), voltage-dependent $\mathrm{Ca}^{2+}$ channels $(62)$, and tyrosine phosphatase (12). In addition, several authors have shown that SS increases the guanylate cyclase activity in several tissues $(11,17,54)$. Recent studies argue that, in contrast to cyclic AMP (57), cyclic GMP has a role in the antiproliferative effect of SS (41).

One strong stimulant of exocrine pancreatic growth in the rat is a total gastrectomy, which results in acinar cell hyperplasia 2 weeks after the intervention (10). To determine whether SS is involved in exocrine pancreas growth responses in vivo, we measured the status of SS binding and pancreatic somatostatin-like immunoreactivity (SS-LI) content in control pancreas and during pancreatic proliferation 2 weeks after gastrectomy in rats. This study also examines the basal activity of the guanylate cyclase

\footnotetext{
'Requests for reprints should be addressed to E. Arilla.
} 
system as well as the stimulatory effect of SS on this enzyme activity in these membranes. Cholecystokinin (CCK) is the major humoral candidate in promoting postgastrectomy pancreatic hyperplasia $(9,29)$. Proglumide, an antagonist of the receptors of the gastrin/CCK peptide family (37), was used to evaluate whether the effects of gastrectomy on the pancreatic somatostatinergic system involved the activation of gastrin/CCK receptors. Protein tyrosine phosphatases have been reported to play a crucial role in cellular processes involving protein phosphorylation such as growth and differentiation (60). The fact that tyrosine phosphatase activity is stimulated by growth factor inhibitors, like SS (50) and transforming growth factor $\beta$ (TGF- $\beta$ ) (20), and by differentiating agents $(51,53)$ that inhibit cell growth suggests an inverse relationship between tyrosine phosphatase activity and cell growth. Therefore, protein tyrosine phosphatase activity was also determined in the membrane preparations previously cited.

METHOD

\section{Materials}

Synthetic [Tyr' ']SS was purchased from Universal Biologicals Ltd. (Cambridge, UK); collagenase (from Clostridium histoliticum) was obtained from Serva Fine Chemicals (Tebu, France). Bacitracin, phenylmethylsulphonylfluoride (PMSF), guanosine triphosphate (GTP), 3-isobutyl-1-methylxanthine (IBMX), bovine serum albumin (BSA), Nonidet P-40, poly(Glu,Tyr) ( $4: 1$ by mass), ammonium molybdate ( $1 \%$ in 1.32 $M \mathrm{HCl}$ ) were purchased from Sigma (St. Louis, MO). $\left[\gamma-{ }^{32} \mathrm{P}\right] \mathrm{ATP}$ was from NEN (Les Ulis, France). Sephacryl S-300 HR was from Pharmacia (Uppsala, Sweden). Carrier-free $\mathrm{Na}\left[{ }^{125} \mathrm{I}\right]$ (IMS 300, $100 \mathrm{mCi} / \mathrm{ml}$ ), the rabbit antibody used in the radioimmunoassay technique, and the cGMP kit were purchased from the Radiochemical Center (Amersham, UK). This antiserum was raised in rabbits against SS conjugated to BSA and is specific for SS, but because SS constitutes the $C$-terminal portion of both somatostatin-25 (SS-25) and somatostatin-28 (SS-28), the antiserum does not distinguish between these three forms. The binding of SS to this antibody does not depend on an intact disulfide bond in the molecule, because breaking the disulfide bond by reaction with $0.1 \%$ mercaptoethanol ( $5 \mathrm{~min}$ boiling water bath) does not change peptide immunoreactivity. Cross-reactivity with other peptides was less than $0.5 \%$. Cross-reaction with several SS analogues demonstrated that neither the $N$-terminal glycine nor the $C$-terminal cysteine residues are required for antibody binding, suggesting that the antigen site is directed towards the central part of the molecule containing the tryptophan residue. All other reagents were of the highest purity commercially available.

\section{Experimental Animals}

Male Wistar rats with an initial body weight of 200-250 g were used for the study. Animals were fasted for $12 \mathrm{~h}$ before surgery. Using ether anesthesia, total gastrectomy was performed through a midline incision by removing the entire stomach. The vagal trunks were preserved and continuity restored by end-toend anastomosis between the esophagus and duodenum. Sham operation was performed by making and repairing an incision in the stomach. In the proglumide-treated groups, the animals received two times daily for 2 weeks an IP injection of proglumide $(20 \mathrm{mg} / \mathrm{kg})$. Proglumide was dissolved in saline solution. Postoperatively the rats were maintained on a $5 \%$ glucose diet for the first $24 \mathrm{~h}$, then allowed free access to standard chow and tap water. These rats were sacrificed by decapitation 2 weeks after the intervention and the pancreas was removed and trimmed free of fat, connective tissucs, and lymph nodes.

\section{Preparation of Rat Pancreatic Acinar Membranes}

Dispersed pancreatic acini were obtained from male Wistar rats after enzymatic degradation of the pancreas with 0.2 units of collagenase/ml in an oxygenated Krebs-Ringer medium as described by Amsterdam et al. (2). After washing by sedimentation, acini were transferred to $0.3 M$ sucrose, $0.03 \%$ soybean trypsin inhibitor, $0.1 \mathrm{~m} M$ PMSF, and $1 \mathrm{~m} M$ benzamidine (buffer $A$ ). In this huffer, the acini were homogenized at $4^{\circ} \mathrm{C}$ by use of a Potter homogenizer. After centrifugation at $600 \times g$ for $5 \mathrm{~min}$ at $4^{\circ} \mathrm{C}$, the supernatant was resuspended in buffer $A$ and centrifuged at $100,000 \times g$ in a TLA 100.3 rotor for $1 \mathrm{~h}$. The supernatant was discarded and the pellet was resuspended in $50 \mathrm{mM}$ Tris- $\mathrm{HCl}$, $\mathrm{pH} 7,0.5 \mathrm{mg} / \mathrm{ml}$ bacitracin, $0.2 \mathrm{mM} \mathrm{CaCl} \mathrm{m}_{2}, 0.03 \%$ soybean trypsin inhibitor, $0.1 \mathrm{~m} M$ PMSF, $1 \mathrm{~m} M$ benzamidine, and 5\% glycerol (buffer B). An aliquot was taken for protein determination by the method of Lowry et al. (27) with bovine serum albumin as a standard.

Binding of $\left[^{125} I-T y r^{\prime \prime}\right] S S$

Binding of $\left[{ }^{125} \mathrm{I}-\mathrm{Ty} \mathrm{r}^{1}\right.$ "]SS was assayed on pancreatic acinar membranes from Wistar rats by a modified method (12). [ [25ITyr $\left.{ }^{\prime \prime}\right]$ SS was radioiodinated by chloramine-T iodination according to the method of Greenwood (19). Separation of iodinated SS from unincorporated iodine was carried out on a Sephadex G-25 (fine) column equilibrated and eluted with $0.1 M$ acetic acid in BSA $(0.1 \% \mathrm{w} / \mathrm{v})$. The specific activity of the radioligand was $600 \mathrm{Ci} / \mathrm{mmol}$

Binding of [ $\left.{ }^{125} \mathrm{I}-\mathrm{Tyr}^{1 /}\right] \mathrm{SS}$ to pancreatic acinar membranes was carried out in a total volume of $250 \mu \mathrm{l}$ in $50 \mathrm{mM}$ Tris- $\mathrm{HCl}$ buffer (pH 7.4) containing $0.5 \mathrm{~m} M \mathrm{MgCl}_{2}, 3 \mathrm{mM} \mathrm{NaCl}, 0.2 \mathrm{mM} \mathrm{CaCl}$, $0.2 \%$ (w/v) BSA, $0.5 \mathrm{mg} / \mathrm{ml}$ bacitracin, and $0.3 \mathrm{mg} / \mathrm{ml}$ soybean trypsin inhibitor (binding buffer). Plasma membranes ( $140 \mu \mathrm{g}$ of protein $/ \mathrm{ml}$ ) were incubated for $90 \mathrm{~min}$ at $20^{\circ} \mathrm{C}$ with $100 \mathrm{pM}\left[{ }^{125} \mathrm{I}-\right.$ $\left.\mathrm{Tyr}^{11}\right] \mathrm{SS}$ in the absence or presence of unlabeled SS. Bound and free ligand was separated by centrifugation at $11,000 \times g$ for 4 $\min$ at $4^{\circ} \mathrm{C}$ in a microcentrifuge. Radioactivity in the pellet was mcasurcd with a gamma scintillation counter. Nonspecific binding was estimated as membrane-associated radioactivity in the presence of $1 \mu M$ SS and specific binding was calculated as the difference between total and nonspecific membrane-associated radioactivity.

\section{Evaluation of Radiolabeled Peptide Degradation}

To determine the extent of tracer degradation during incubation, we measured the ability of preincubated peptide to bind to fresh pancreatic acinar membranes. Briefly, $\left[{ }^{125} \mathrm{~T}-\mathrm{Tyr}^{11}\right] \mathrm{SS}(100$ $\mathrm{p} M)$ was incubated with pancreatic acinar membranes $(140 \mu \mathrm{g}$ protein $/ \mathrm{ml}$ ) for $90 \mathrm{~min}$ at $20^{\circ} \mathrm{C}$. After this preincubation, aliquots of the medium were added to fresh pancreatic acinar membranes and incubated for an additional $90 \mathrm{~min}$ at $20^{\circ} \mathrm{C}$. The fraction of the added radiolabeled peptide that specifically bound during the second incubation was measured and expressed as a percentage of the binding that was obtained in control experiments performed in the absence of pancreatic acinar membranes during the preincubation period. Pancreatic acinar cell membranes from all the groups showed a similar peptide degradation capacity and the values varied by no more than $9 \%$ in all the experimental groups.

\section{Measurement of the Particulate Guanylate Cyclase Activity}

The activity of particulate guanylate cyclase in pancreatic acinar membranes was measured using the method previously described $(16,25)$ with a slight modification. The membranes $(50$ $\mu \mathrm{g}$ protein $/ 10 \mu \mathrm{l}$ ) were resuspended in $50 \mathrm{~m} M$ Tris- $\mathrm{HCl}, \mathrm{pH} 7.6$, 
and used for the assay of guanylate cyclase activity. A $10-\mu 1$ aliquot of the particulate fraction was added to tubes containing $80 \mu \mathrm{l}$ of a reaction mixture containing (final concentrations) 50 $\mathrm{m} M$ Tris-HCl, pH 7.6, $40 \mathrm{~m} M \mathrm{MnCl}_{2}, 1 \mathrm{~m} M$ GTP, $1 \mathrm{~m} M$ IBMX, $0.01 \%$ bacitracin, and a GTP-regenerating system that consisted of $1.5 \mathrm{mM}$ creatine phosphate and $20 \mu \mathrm{g}$ of creatine phosphokinase. After incubation at $37^{\circ} \mathrm{C}$ for $10 \mathrm{~min}$ with or without SS $\left(10^{-7}-10^{-12} M\right)$ the reaction was stopped by the addition of 900 $\mu l$ of $50 \mathrm{mM}$ sodium acetate, $\mathrm{pH} 4.0$, followed by heating at $90^{\circ} \mathrm{C}$ for $3 \mathrm{~min}$. The heated incubation mixture was centrifuged at 2000 $\times g$ for $20 \mathrm{~min}$ and the supernatant fraction was evaporated to dryness. The amount of cyclic GMP generated was determined in the dry extract by radioinmunoassay.

\section{Tissue Extraction and SS Radioimmunoassay}

For SS-LI measurement, the pancreata were rapidly homogenized in $1 \mathrm{ml} 2 \mathrm{M}$ acetic acid using a Brinkman polytron (setting $5,30 \mathrm{~s}$ ). The extracts were boiled for $5 \mathrm{~min}$ in an ice-chilled water bath, and aliquots $(100 \mu \mathrm{l})$ were removed for protein determination (27). The homogenates were subsequently centrifuged at $15,000 \times g$ for $15 \mathrm{~min}$ at $4^{\circ} \mathrm{C}$ and the supernatant was neutralized with $2 \mathrm{MNaOH}$. The extracts were stored at $-70^{\circ} \mathrm{C}$ until assay. The SS concentration was determined in tissue extracts by a modified radioimmunoassay method (36), with a sensitivity limit of $10 \mathrm{pg} / \mathrm{ml}$. Incubation tubes prepared in duplicate contained $100-\mu l$ samples of tissue extracts or standard solutions of $0-500 \mathrm{pg}$ cyclic SS diluted in phosphate buffer $(0.05 \mathrm{M}, \mathrm{pH}$ 7.2, containing $0.3 \%$ BSA, $0.01 M$ EDTA), $200 \mu$ l appropriately diluted anti-SS-serum, $100 \mu$ l freshly prepared $\left.{ }^{125}{ }^{12}-\mathrm{Tyr}^{11}\right] \mathrm{SS}$ diluted in buffer to give $6000 \mathrm{cpm}$ (equivalent to $5-10 \mathrm{pg}$ ), in a final volume of $0.8 \mathrm{ml}$. All reagents as well as the assay tubes were kept chilled on ice before incubation for $48 \mathrm{~h}$ at $4^{\circ} \mathrm{C}$. Bound hormone was separated from free hormone by the addition of 1 $\mathrm{ml}$ dextran-coated charcoal (dextran T-70, 0.2\% w/v, Pharmacia; charcoal: Norit A, 2\% w/v. Serva, Feinbiochemica, Heidelberg, Germany). Serial dilution surves for the samples were parallel with the standard curve. The intra- and interassay variation coefficients were $6.0 \%$ and $8.8 \%$, respectively.

\section{Preparation of A43I Membranes}

A431 cells were washed once with $10 \mathrm{~m} M$ sodium phosphate, $\mathrm{pH} 7$, and $150 \mathrm{mM} \mathrm{NaCl}\left(\mathrm{NaCl} / \mathrm{P}_{\mathrm{i}}\right)$ and scraped into $10 \mathrm{mM} \mathrm{NaCl}$ $\mathbf{P}_{\mathrm{i}}, \mathrm{pH} 7$ (18). The cells were collected by centrifugation, suspended in $50 \mathrm{mM}$ Tris-HCl, pH 7, containing $0.03 \%$ soybean trypsin inhibitor, $0.5 \mathrm{mg} / \mathrm{ml}$ bacitracin, and lysed by freezethawing in liquid nitrogen. The lysate was centrifuged at $170 \times$ $g$ for $5 \mathrm{~min}$. The subsequent supernatant was centrifuged at $25,000 \times g$ for $30 \mathrm{~min}$. The final pellet was resuspended in the $50 \mathrm{~m} M$ Tris- $\mathrm{HCl}, \mathrm{pH} 7$, containing $0.03 \%$ soybean trypsin inhibitor and $0.5 \mathrm{mg} / \mathrm{ml}$ bacitracin (12).

\section{Preparation of Phosphorylated Poly(Glu,Tyr)}

Phosphorylated poly(Glu,Tyr) was prepared by incubating 7.2 mg polymer with $1.5-2 \mathrm{rng}$ A431 cell membranes in $50 \mathrm{mM}$ Tris-HCl, containing $0.1 \mu M$ epidermal growth factor, $250 \mu M$ $\left[\gamma^{-32}\right.$ P]ATP $(700 \mathrm{dpm} / \mathrm{pmol}), 100 \mu M$ orthovanadate, $5 \mathrm{mM}$ $\mathrm{MnCl}_{2}$, and $0.1 \%$ Nonidet $\mathrm{P}-40$ at $\mathrm{pH} 7.5$ (12). The reaction was allowed to proceed for $16 \mathrm{~h}$ at $4^{\circ} \mathrm{C}$, then the mixture was subjected to gel filtration on a Sephacryl S300 HR column. Fractions containing the phosphorylated poly(Glu,Tyr) were pooled and concentrated in a Centricon-3 Amicon microconcentrator; 100$\mu \mathrm{l}$ aliquots were stored at $-20^{\circ} \mathrm{C}$.

\section{Assay for Phosphotyrosine Phosphatase Activity}

PTPase activity was measured by the release of $\left[{ }^{32} \mathrm{P}\right]$ orthophosphate from ${ }^{32} \mathrm{P}$-labeled poly(Glu, Tyr) in a $100-\mu 1$ reaction mixture containing $30,000 \mathrm{cpm}{ }^{32} \mathrm{P}$-labeled poly(Glu,Tyr) (final concentration of $0.3 \mu \mathrm{M}$ ) and $3 \mu \mathrm{g}$ acinar pancreatic membrane proteins in buffer $B$ containing $0.1 \%$ albumin. The reaction was allowed to proceed for $5 \mathrm{~min}$ at $30^{\circ} \mathrm{C}$, then stopped by the addition of $100 \mu 130 \%$ trichloroacetic acid. The mixtures were kept on ice for $30 \mathrm{~min}$, then centrifuged at $10,000 \times \mathrm{g}$ for $10 \mathrm{~min}$ to remove the denatured proteins. The inorganic $\left[{ }^{32} \mathrm{P}\right]$ phosphate liberated was extracted using the molybdate extraction procedure (3) and radioactivity was evaluated by liquid scintillation. The amount of ${ }^{32} \mathrm{P}_{\mathrm{i}}$ releascd was determined from the specific radioactivity of $\left[\gamma-{ }^{32} \mathrm{P}\right]$ ATP used for the phosphorylation reaction. One unit PTPase activity was defined as the amount that released $1 \mathrm{nmol}$ phosphate $/ \mathrm{min}$ at $30^{\circ} \mathrm{C}$ from radiolabeled substrate.

\section{Data Analysis}

The computer program LIGAND (34) was used to analyze the binding data. The use of this program made it possible to select the receptor models that best fit a given set of binding data. The same program was also used to present data in the form of Scatchard plots (44) and to compute the values for receptor affinity $\left(K_{d}\right)$ and density $\left(B_{\max }\right)$ that best fit the sets of binding data for each rat. Statistical comparisons of all the data were analyzed by ANOVA and the Newman-Keuls $t$-test. Means among groups were considered significantly different when the value was $p<0.05$. Each individual experiment was performed in duplicate.

\section{RESULTS}

Two weeks following total gastrectomy, the weight of the pancreas increased significantly by $30 \%(p<0.001)$ when compared to sham-operated rats. Pancreatic acinar membrane PTPase activity decreased (74\% of control) 2 weeks after total gastrectomy, coinciding with hyperplasia of exocrine pancreatic tissue previously described (Fig. 1).

Figure 2 shows that pancreatic SS-LI content 2 weeks after total gastrectomy was significantly lower (55\% of control levels) than in control rats.

The specific binding of SS to rat pancreatic acinar membranes increased (146\% of control) after gastrectomy compared to con-

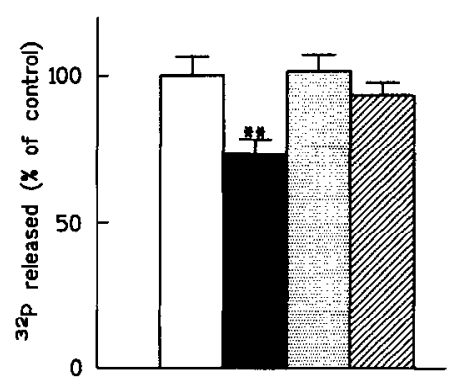

FIG. 1. Rat pancreatic acinar membrane phosphotyrosine phosphatase (PTPase) activity. Crude membranes were prepared as described in the Method section. PTPase activity was expressed as a percentage of control activity obtained with pancreatic acinar membranes from sham-operated rats. Control values averaged $0.13 \pm 0.009 \mathrm{nmol} / \mathrm{mg}$ protein $/ \mathrm{min}$. Results are means \pm SEM of five different experiments performed in duplicate. ${ }^{* *} p<0.01$ vs. respective control. Open bar: sham-operated; black bar: gastrectomized; speckled bar: gastrectomized plus proglumide; hatched bar: proglumide alone. 


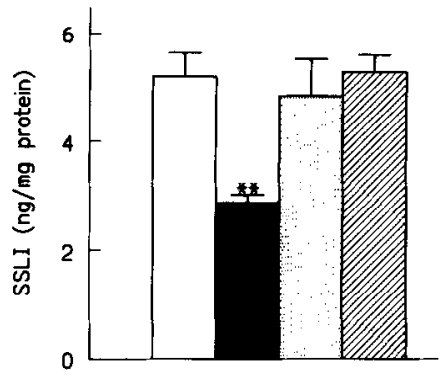

FIG. 2. Pancreatic somatostatin-like immunoreactivity (SS-LI) content in sham-operated (open bar), gastrectomized (black bar), gastrectomized plus proglumide-treated (speckled bar), and proglumide-treated (hatched bar) rats. Values are expressed as the mean \pm SEM in ng SS/mg protein for five rats per group performed in duplicate. Statistical comparison vs. control: ${ }^{* *} p<0.01$

trol conditions. When comparing the corresponding curves of $\left[{ }^{125} \mathrm{I}-\mathrm{Tyr}^{\prime \prime}\right] \mathrm{SS}$ displacement by increasing concentrations of the unlabeled peptide (Fig. 3), the binding data were significantly higher in the gastrectomized group throughout the whole range studicd. Scatchard plots of the stoichiometric binding data were linear and essentially parallel (Fig. 3, right panel). Interpretation of these data with the LIGAND computer program (34) resulted in the best fit for a model with one type of SS receptor. Pancreatic acinar membranes from gastrectomized rats exhibited significant increases in the maximum SS binding capacity. However, the corresponding $K_{\mathrm{d}}$ values remained unchanged after gastrectomy.

The modulation of guanylate cyclase by SS was studied in pancreatic acinar membranes from control and gastrectomized rats. No significant differences were seen for basal guanylate cyclase activities between the control group and the gastrectomized group. The capacity of SS to stimulate guanylate cyclase activity in control and gastrectomized rats is shown in Table 2. SS increased by twofold guanylate cyclase activity in pancreatic membranes from gastrectomized rats.

Because the major humoral candidate for promoting pancreatic hyperplasia after gastrectomy appears to be CCK $(9,29)$, a group of gastrectomized rats was treated with proglumide, an antagonist of receptors of the gastrin/CCK peptide family to evaluate whether the effects of gastrectomy on the pancreatic somatostatinergic system involved the activation of gastrin/CCK. Proglumide suppressed the inhibitory effect of gastrectomy on basal tyrosine phosphatase activity and SS-LI content which returned to control levels (Figs. 1 and 2). Furthermore, proglumide suppressed the increase of the number of SS receptors and that of guanylate cyclase activity induced by gastrectomy (Fig.3, Tables 1 and 2). Proglumide was also administered to sham-operated control rats without producing significant differences with the controls in any of the studied parameters.

\section{DISCUSSION}

Gastrectomy increased pancreatic growth (10) and this effect was associated with an increase in the number of SS receptors without alteration of affinity.

The molecular basis for the increased number of SS receptors after gastrectomy is uncertain. Because growth factor-induced cell division is paralleled by heteroregulation of other cell surface receptors (7), it is possible that SS receptors are targets for heterologous regulation by growth factors. Thus, the increase of SS receptors could be secondary to the CCK mitogenic signal $(13,32)$. In this regard, the CCK receptors seem to mediate the action of gastrectomy on the SS receptor-effector system in the pancreatic acinar membranes because the gastrectomy-induced changes in the somatostatinergic system were prevented by the gastrin/CCK receptor antagonist proglumide. In addition, proglumide alone had no demonstrable effect on these parameters. Two types of receptors for the gastrin/CCK peptide family have been identified in pancreatic acinar cells $(37,59)$ : the $\mathrm{CCK}_{\mathrm{A}}$ receptors, which have a much higher affinity for CCK than for gastrin (37); and the gastrin receptors $\left(\mathrm{CCK}_{\mathrm{B}}\right.$ or $\left.\mathrm{GR}\right)$, which have approximately the same affinity for CCK and gastrin (37).

The increase in the number of SS receptors observed during pancreatic acinar cell hyperplasia 2 weeks after total gastrectomy is consistent with the view that SS may function as a negative regulator of pancreatic acinar cell proliferation in vivo $(31,42,46)$. Pancreatic acinar cells, which do not synthesize SS but possess functional receptors for SS $(48,58)$, may respond to SS produced in the pancreas by the D cells in the islets of Langerhans as well as to circulating SS.

Recently we found that exocrine pancreatic growth observed after proximal small bowel resection is accompanied by an increase in the number of SS receptors at 2 weeks and 1 month after intestinal surgery (1). In addition, in pancreatic tumor cells AR42J, we also observed an increase in the number of SS receptors after treatment of cells with gastrin and epidermal growth factor (EGF) (and with CCK, not published), which stimulate cell growth (55). In contrast, conditions that decrease cell growth, such as treatment with glucocorticoids, decrease the number of SS receptors on AR42J cells (56). All these results suggest that pancreatic acinar cell growth is associated with upregulation of SS receptors and this could represent a mechanism promoted by the cell to negatively regulate the mitogenic activity of pancreatic growth factors such as CCK.

Although at least five SS receptor subtypes have been cloned (6), only SSTR3 (63) and SSTR5 (38) are present in the islets of Langerhans whereas the exocrine pancreas appears to express only receptor subtype 2 (SSTR2) (8). Vidal et al. (55) also reported that AR42J cells expressed SSTR2 subtype strongly and that the gastrin- and EGF-induced increase in SS receptors was due to upregulation in SSTR2 subtype receptors. All these results suggest that the increase in SS receptor number after gastrectomy

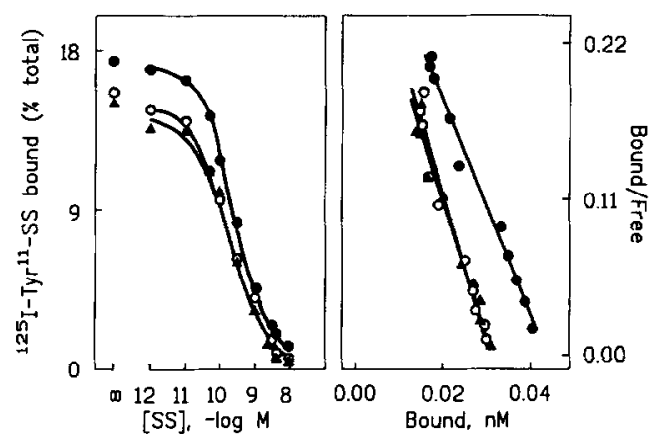

FIG. 3. Left panel: competitive inhibition of specific [ $\left.{ }^{125} \mathrm{I}-\mathrm{Tyr}{ }^{11}\right]$ somatostatin $\left(\left[^{125} \mathrm{I}-\mathrm{Tyr}^{i}\right] \mathrm{SS}\right)$ binding to rat pancreatic acinar membranes by unlabeled somatostatin. Points correspond to sham-operated $(O)$, gastrectomized $(\bullet)$, and gastrectomized plus proglumide $(\Delta)$ rats. Each point is the mean of five separate experiments, each performed in duplicate. Results express the value of a pool of control groups because maximal binding capacity and dissociation constant values of the control groups were not affected. For the sake of clarity, SEM are not represented but were always below $10 \%$ of mean values. Right panel: Scatchard analysis of the same data. The kinetic constants calculated by Scatchard analysis are given in Table 1. 
TCABLE 1

EQUILIBRIUM PARAMETERS FOR SOMATOSTATIN (SS) BINDING TO PANCREATIC ACINAR MEMBRANES OF RATS THAT UNDERWENT A SHAM OPERATION, TOTAL CASTRECTOMY, TOTAL GASTRECTOMY PLUS PROGLUMIDE ADMINISTRATION, OR PROGLUMIDE ADMINISTRATION ALONE

\begin{tabular}{lll}
\hline \multirow{1}{*}{ Groups } & \multicolumn{2}{c}{ SS Receptors } \\
\cline { 2 - 3 } & $B_{\text {max }}$ (fmol/mg prolein) & $K_{\mathrm{d}}(\mathrm{mM})$ \\
\hline Sham operated & $216 \pm 21$ & $0.09 \pm 0.007$ \\
Gastrectomized & $316 \pm 30^{*}$ & $0.13 \pm 0.008$ \\
Gastrectomized + proglumide & $222 \pm 17$ & $0.10 \pm 0.006$ \\
Proglumide & $218 \pm 13$ & $0.09 \pm 0.008$ \\
\hline
\end{tabular}

Binding parameters were obtained by computer nonlinear regression analysis (LIGAND) of individual competitive binding curves. Each value is the mean \pm SEM of five separate experiments performed in duplicate. Comparison of means within each parameter group was by one-way ANOVA and Newman-Keuls tests.

* Statistical comparison versus control: $p<0.01$.

could result, at least in part, from upregulation of the SSTR2 subtype.

With respect to postreceptor mechanisms, recently Viguerie et al. (57) and Alvaro-Alonso et al. (1) reported that the cyclic AMP pathway is not involved in the inhibitory effect of SS of pancreatic cell growth. Because recent papers support a role for cyclic GMP in the antiproliferative effect of SS (41), the present study has examined the effect of SS on guanylate cyclase activity in pancreatic acinar cell membranes from control and gastrectomized rats. The cyclic GMP levels in pancreatic acinar membranes obtained in the present study are similar to those obtained by García-Escribano et al. (17) in mesangial cells and by Catalan et al. (11) in the cerebral cortex, and lower than those obtained by Vesely et al. (54) in the pancreas. However, the two latter authors measured the guanylate cyclase activity in the supernatant, whereas our study and that of García-Escribano et al. (17) measured the guanylate cyclase activity in the pellet. The present results show that SS increases guanylate cyclase activity significantly in the operated rats. However, the increase is not significant in the control rats, where it is comparable to the effect of proglumide alone. The increase does not appear to be due to a change in the number of molecules of guanylate cyclase itself because the activity levels were similar in membranes from hoth control and gastrectomized animals. The intensity of the stimulatory effect of SS on guanylate cyclase activity in the gastrectomized animals is most probably related to the observed increase in SS receptors. These results demonstrate for the first time that SS stimulates membrane guanylate cyclase activity in pancreatic acinar cells. This effect is ohserved at a SS concentration that correlates with the affinity of SS for pancreatic SS receptors (22) and could be involved in the inhibitory effect of SS on pancreatic cell growth.

In addition to the intestinal mucosa, which preferentially releases SS-28 (5), a major site of endogenous SS release is located within the pancreas itself, namely in the D cells of the islets of Langerhans. The close interaction between the islets and the exocrine tissue appears to be at least partially mediated by an insuloacinar portal system $(26,35)$. Thus, because of the relatively short plasmatic half-life of SS, which has been estimated to be approximately $1-2 \mathrm{~min}$ for SS and approximately $4 \mathrm{~min}$ for SS$28(52)$, it seems that islet-released SS might act via the insuloacinar portal system (33). Hence, despite low peripheral plasma levels, relatively high local plasma concentrations would be present around the acinar tissue and this probably has functional relevance (33). Therefore, the present study measured pancreatic SS-LI content. The pancreatic SS-LI levels in the control rats were similar to those previously reported by others (36). Gastrectomy decreased pancreatic SS-LI content compared with controls. These results also agree with other experimental models of pancreatic growth studied by our group. Thus, two weeks after enterectomy, the situation is similar: increased SS receptors and decreased SS-LI (albeit not significant after enterectomy). Total gastrectomy leads to increased CCK (29) and glucagon (14) plasma levels compared to controls. Because it has been demonstrated that CCK and glucagon increases SS secretion (30), the decrease of pancreatic SS-LI levels in response to gastrcctomy could be a consequence of increased plasma levels of both hormones.

Cell membrane-associated tyrosine phosphatase activities have been characterized in various tissues $(15,24)$. Recently, Colás et al. (12) demonstrated that the level of tyrosine phosphatase activity in rat pancreatic acinar cells is as high as that observed in some rich sources of tyrosine phosphatase such as rat spleen (49) or rabbit kidney (47). The control values of the present study are in agreement with previously reported values. Gastrectomy decreased tyrosine phosphatase activity. The regulation of protein phosphorylation level in tyrosine residues is well known to be involved in cellular activities associated with growth and dif-

TABLE 2

EFFECT OF SOMATOSTATIN (SS) ON GUANYLATE CYCLASE ACTIVITY IN PANCREATIC ACINAR MEMRRANES OF RATS THAT UNDERWFNT A SHAM OPERATION, TOTAL GASTRECTOMY, TOTAL GASTRECTOMY PLUS PROGLUMIDE ADMINISTRATION, OR PROGLUMIDE ADMINISTRATION ALONE

\begin{tabular}{ccccc}
\hline [SS] & Sham-Operated & Gastrectomized & Gastrectomized + Proglumide & Proglumide \\
\hline 0 & $9.3 \pm 1.5$ & $9.8 \pm 0.9$ & $9.5 \pm 0.7$ & $9.8 \pm 1.4$ \\
$1 \mathrm{pM}$ & $10.8 \pm 0.9$ & $11.8 \pm 1.7$ & $10.8 \pm 1.9$ & $10.3 \pm 0.03$ \\
$10 \mathrm{pM}$ & $11.5 \pm 0.5$ & $13.8 \pm 1.3$ & $11.5 \pm 1.3$ & $11.1 \pm 0.8$ \\
$100 \mathrm{pM}$ & $13.8 \pm 1.2$ & $16.3 \pm 1.8$ & $13.3 \pm 0.6$ & $13.6 \pm 1.2$ \\
$1 \mathrm{nM}$ & $14.4 \pm 1.2$ & $19.2 \pm 0.4^{*}$ & $14.3 \pm 1.5$ & $14.2 \pm 1.6$ \\
$1.0 \mathrm{nM}$ & $13.7 \pm 1.0$ & $16.9 \pm 0.7 \dagger$ & $13.4 \pm 0.2$ & $13.5 \pm 1.4$ \\
$100 \mathrm{nM}$ & $12.6 \pm 0.8$ & $13.0 \pm 0.8$ & $12.4 \pm 0.2$ & $12.5 \pm 1.9$ \\
\hline
\end{tabular}

Values are means \pm SEM of determinations performed in pmol cyclic GMP/mg protein/10 min of incubation. Experiments were performed as described in the Method section.

* $\dagger$ Statistical comparison vs. control: ${ }^{*} p<0.01,+p<0.05$. 
ferentiation. Indeed, it has been demonstrated that CCK stimulated tyrosine kinase activity in pancreatic acini (28) and this stimulation is associated with the growth-promoting effect of caerulein (40). Conversely, SS stimulation of membrane tyrosine phosphatase activity has been shown to be involved in the antiproliferative effect of SS in pancreatic tumor cells (50). The decrease of tyrosine phosphatase activity observed after gastrectomy is like that observed after pancreatectomy during the regeneration process associated with pancreatic growth (40). These observations suggest that the negative regulation of tyro- sine phosphatase activity may be important in the events involved in the pancreatic hyperplasia observed after gastrectomy.

\section{ACKNOWLEDEGEMENTS}

The authors thank Carol F. Warren from the Alcalá de Henares University Institution of Education Sciences and Lilian Puebla from the Department of Biochemistry of Alcalá de Henares University for their linguistic assistance as well as Angela Martín-Espinosa for her invaluable technical assistance. This study was supported by a Grant (PB94-0339) from the Dirección General de Investigación Científica y Técnica of Spain.

\section{REFERENCES}

1. Alvaro-Alonso, I.; Colás, B.; Esteve, J. P.; Susini, C.; Arilla, E. Somatostatin receptor-effector system in rat pancreatic acinar membranes after subtotal enterectomy. Am. J. Physiol. 268:E343-E348; 1995.

2. Amsterdam, A.; Salomon, T. E.; Jamieson, I. D. Sequential dissociation of the exocrine pancreas into lobules, acini and individual cells. Methods Cell. Biol. 20:361 -378; 1978.

3. Antoniw, J. F.; Cohen, P. Separation of two phosphorilase kinase phosphatases from rabbit skeletal muscle. Eur. J. Biochem. 68:45$54 ; 1976$.

4. Arimura, A.; Haruko, S.; Dupont, A.; Nishi, N.; Schally, A. V. Somatostatin: Abundance of immunoreactive hormone in rat stomach and pancreas. Science 189:1007-1009; 1975.

5. Baldissera, F. G. A.; Nielsen, O. V.; Holst, J. J. The intestinal mucosa preferentially releases somatostatin-28 in pigs. Regul. Pept. 11:251-262; 1985

6. Bell, G. I.; Reisine, T. Molecular biology of somatostatin receptors. Trends Neurol. Sci. 16:34-38; 1993.

7. Bold, R. J.; Ishizuka, J; Townsed, C. M.; Thompson, J. C. Biomolecular advances in gastrointestinal hormones. Arch. Surg. 128:1268-1273; 1993

8. Bruno, J. F.; Xu, Y.; Song, J.; Berelowitz, M. Tissue distribution of somatostatin receptor subtype messenger ribonucleic acid in the rat. Endocrinology 133:2561 - 2567; 1993.

9. Büchler, M.; Malfertheiner, P.; Friess, H.; Nustede, R.; Feurle, G. E.; Beger, H. G. Cholecystokinin influences pancreatic trophism following total gastrectomy in rats. Int. J. Pancreatol. 4:261-271; 1989.

10. Büichler, M.; Malfertheiner, P.; Glasbrenner, B.; Beger, H. G. Rat exocrine pancreas following total gastrectomy. Int. J. Pancreatol. $1: 389-398 ; 1986$.

11. Catalán, R. E.; Aragonés, M. D.; Martínez, A. M. Somatostatin effect on cyclic GMP levels in rat brain. Biochim. Biophys. Acta 586:213 $216 ; 1979$.

12. Colás, B.; Cambillau, C.; Buscail, L.; et al. Stimulation of a membrane tyrosine phosphatase activity by somatostatin analogues in rat pancreatic acinar cells. Eur. J. Biochem. 207:1017-1024; 1992.

13. Dembinsky, A. B.; Johnson, L. R. Stimulation of pancreatic growth by secretin, caerulein and pentagastrin. Endocrinology 16:323-328; 1980.

14. Duong, T. N.; Ghazi, A.; Levan, V. H. Glucagon and insulin release in totally gastrectomized rats. Exp. Pathol. 27:227-231; 1985.

15. Fischer, E. H.; Charbonneau, H.; Tonks, N. K. Protein tyrosine phosphatases: A diverse family of intracellular and transmembrane enzymes. Science 253:401-406; 1991.

16. Garbers, D. L.; Murad, F. Guanylate cyclase assay methods. Adv. Cyclic Nucl. Res. 10:57-67; 1979.

17. García-Escribano, C.; Díez-Marqués, M. L.; Medina Alonso, J.; Rodríguez-Puyol, M.; Rodríguez-Puyol, D. Somatostatin activates particulate guanylate cyclase in cultured rat mesangial cells. Kidney Int. 46:1611-1615; 1994.

18. Giard, D. J.; Aaronson, S. A.; Todaro, G. J.; et al. In vitro cultivation of human tumors: Establishment of cell lines derived from a series of solid tumor. I. Natl. Cancer Int. 51:1417-1423; 1973.

19. Grenwood, F. C.; Hunter, W. M.; Glover, J. S. The preparation of $\left[{ }^{131} I\right]$-labeled human growth hormone of high specific radioactivity. Biochem. J. 89:114-123; 1963.
20. Gruppuso, P. A.; Mikumo, R.; Brautigan, D. L.; Braun, L. Growth arrest induced by trasnsforming growth factor $\beta 1$ is accompanied by protein phosphatase activation in human keratinocytes. J. Biol. Chem. 266:3444-3448; 1991.

21. Hökfelt, T.; Efendic, S.; Hellerstrom, C.; Johansson, O.; Luft, R.; Arimura, A. Cellular localization of somatostatin in endocrine-like cells and neurons of the rat with special references to the A1 cells of the pancreatic islets and to the hypothalamus. Acta Endocrinol. (Copenh.) 200(Suppl. 80):5-41; 1975.

22. Knuthsen, S.; Esteve, J. P.; Bernadet, B.; Vaysse, N.; Susini, C. Molecular characterization of the solubilized receptor of somatostatin from rat pancreatic acinar membranes. Biochem. J. 254:641$647 ; 1988$.

23. Lambert, S. W. J.; Krenning, E. P.; Reubi, J. C. The role of somatostatin and its analogs in the diagnosis and treatment of tumors. Endocr. Rev. 12:450-482; 1991

24. Lau, K. H. W.; Farley, J. F.; Baylink, D. J. Phosphotyrosyl protein phosphatases. Biochem. J. 257:23-26; 1989.

25. Leitman, D. C.; Andresen, J. W.; Catalano, R. M.; Waldman, S. A.; Tuan, J. J.; Murad, F. Atrial natriuretic peptide binding, crosslinking and stimulation of cyclic GMP accumulation and particulate guanylate cyclase activity in cultured cells. J. Biol. Chem. 263:3720$3728 ; 1988$

26. Lifson, I.; Lassa, C. V.; Disit, P. K. Relation between blood flow and morphology in islet organ of rat pancreas. Am. J. Physiol. 49:E43-E48; 1985.

27. Lowry, O. H.; Rosebrough, N. J.; Farr, A. L.; Randall, R. J. Protein measurement with the Folin phenol reagent. J. Biol. Chem. 193:265-275; 1951.

28. Lutz, M. P.; Sutor, S. L.; Abraham, R. T.; Miller, L. J. A role for cholecystokinin-stimulated protein tyrosine phosphorylation in regulated secretion by the pancreatic acinar cell. J. Biol. Chem. 268:11119-11124; 1993 .

29. Malfertheiner, P.; Büchler, M.; Glasbrenner, B.; Schafmayer, A.; Ditschuneit, $H$. Adaptative changes of the exocrine pancreas and plasma cholecystokinin release following subtotal gastric resection in rats. Digestion 38:142-151; 1987.

30. McIntosh, C. H. S.; Pederson, R. A. Local somatostatin secretion from the pancreas and stomach: In vitro studies. In: Bloom, S. R.; Polak, J. M., eds. Gut hormones, 2nd ed. Edinburgh: Churchill Livingstone; 1981:362-365.

31. Morisset, J. Somatostatin: A potential antigrowth factor for the exocrine pancreas. Regul. Pept. 10:11-22; 1984.

32. Morisset, J. R.; Solomon, T. W.; Grossman, M. R. Effect of secretin and caerulein on pancreatic weight DNA synthesis and content. Gastroenterology 76:1206-1211; 1979.

33. Müller, M. K.; von Schönfeld, J.; Singer, M. V. Role of somatostatin in regulation of insulino-acinar axis. Dig. Dis. Sci. 38:1537-1542; 1993.

34. Munson, P. J.; Rodbard, D. LIGAND: A versatile computerized approach for characterization of ligand binding systems. Anal. Biochem. 1207:220-239; 1980.

35. Murakami, T.; Fujita, T. Microcirculation of the rat pancreas, with special reference to the insulo-acinar portal and insulovenous drainage systems: A further scanning electron microscope study of corrosion casts. Arch. Histol. Cytol. 55:453-476; 1992. 
36. Patel, Y. C.; Reichlin, S. Somatostatin in hypothalamus, extrahypothalamic brain and peripheral tissues of the rat. Endocrinology 102:523-531; 1978.

37. Presti, M.; Gardner, J. D. Receptor antagonists for gastrointestinal peptides. Am. J. Physiol. 264:G339-G406; 1993.

38. Raulf, F.; Hoyer, D.; Bruns, C. Differential expression of five somatostatin receptor subtypes, SSTR 1-5, in the CNS and peripheral tissue. Digestion 55(Suppl. 3):46-53; 1994.

39. Rauly, I.; Cambillau, C.; Sarfati, P.; et al. Cloning, expression and regulation by dexamethasone of a tyrosine phosphatase containing two $\mathrm{SH} 2$ domains in AR42J cells. Giastroenterology 106:A431; 1994.

40. Rivard, N.; Lebel, D.; Lainé, J.; Morisset, J. Regulation of pancreatic tyrosine kinase and phosphatase activities by cholecystokinin and somatostatin. Am. J. Physiol. 266:Gl130-G1138; 1994.

41. Ruiz-Torres, P.; Lucio, F. J.; González-Rubio, M.; RodríguezPuyol, M.; Rodríguez-Puyol D. A dual effect of somatostatin on the proliferation of cultured rat mesangial cells. Biochem. Biophys. Res. Commun. 195:1057-1062; 1993.

42. Rünzi, M.; Müller, M. K.; Goebell, H. Endogenous somatostatin possibly controls pancreatic growth: Further evidence for feedback regulation. Regul. Pept. 47:65-72; 1993

43. Sakamoto, C.; Matozaki, T.; Nagao, M.; Baba, S. Coupling of guanine nucleotide inhibitory protein to somatostatin receptors on pancreatic acinar membranes. Am. J. Physiol. 253:G308-G314; 1987.

44. Scatchard, G. The attractions of proteins for small molecules and ions. Ann. NY Acad. Sci. 51:669-671; 1949.

45. Schally, A. V. Oncological applications of somatostatin analogues. Cancer Res. 48:6977-6985; 1988

46. Senegas-Balas, F.; Balas, D.; Pradayrol, L.; Laval, J.; Bertrand, C.; Ribet, A. Long-term effect of somatostatin 14 on mouse stomach, antoum, intestine and exocrine pancreas. Acta Anat. 121:124-132; 1985.

47. Shriner, C. L.; Brautigan, D. L. Cytosolic protein phosphotyrosine phosphatases from rabbit kidney. J. Biol. Chem. 259:11383-11390; 1984.

48. Srikant, C. B.; Patel, Y. C. Somatostatin receptors on rat pancreatic acinar cells. Pharmacolcigical and structural characterization and demonstration of downregulation in streptozotocin diabetes, J. Biol. Chem. 261:7690-7696; 1986.

49. Swarup, G.; Subrahmanyan, G. Purification and characterization of a protein-phosphotyrosine phosphatase from rat spleen which dephosphorylates and inactivates a tyrosine-specific protein kinase. $\mathbf{J}$. Biol. Chem. 264:7801-7808; 1989.

50. Tahiri-Jouti, N.; Cambillau, C.; Viguerie, N.; et al. Characterization of a membrane tyrosine phosphatase in AR42J cells: Regulation by somatostatin. Am. J. Physiol. 262:G1007-G1024; 1992.
51. Uchida, T.; Matozaki, T.; Matsuda, K.; et al. Phorbol ester stimulates the activity of a protein tyrosine phosphatase containing $\mathrm{SH} 2$ domains (PTP1C) in HL-60 leukemia cells by increasing gene expression. J. Biol. Chem. 168:11845-11850; 1993.

52. Vaysse, N.; Chayvialle, J. A.; Pradayrol, L.; et al. Somatostatin 28: Comparison with somatostatin 14 for plasma kinetics and low-dose effects on the exocrine pancreas in dogs. Gastroenterology 81:700$706 ; 1981$.

53. Vaysse, N.; Pradayrol, L.; Susini, C.; Chayvialle, J. A.; Ribet, A. Somatostatin 28: Biological actions. In: Bloom, S. R.; Polak, J. M. eds. Gut hormones, 2nd ed. Edinburgh: Churchill Livingstone; 1981:358-361.

54. Vesely, D. L. The interrelationship of somatostatin and guanylate cyclase activity. Mol. Cell Biochem. 32:131-134; 1980.

55. Vidal, C.; Rauly, I.; Zeggari, M.; et al. Up-regulation of somatostatin receptors by epidermal growth factor and gastrin in pancreatic cancer cells. Mol. Pharmacol. 45:97-104; 1994.

56. Viguerie, N.; Esteve, J. P.; Susini, C.; Logsdon, C. D.; Vaysse, N.; Ribet, A. Dexamethasone effects on somatostatin receptors in pancreatic acinar AR42J cells. Biochem. Biophys. Res. Commun. 147:942-948; 1987.

57. Viguerie, N.; Tahiri-Jouti, N.; Ayral, A. M.; et al. Direct inhibitory effects of a somatostatin analog; SMS 201-995, on a AR4-2J cell proliferation via pertussis toxin-sensitive guanosine triphosphatebinding protein-independent mechanism. Endocrinology 124:1017$1025 ; 1989$.

58. Viguerie, N.; Tahiri-Jouti, N.; Esteve, J. P.; et al. Functional somatostatin receptors on a pancreatic acinar cell line. Am. J. Physiol. 255:6113-6120; 1988.

59. Vinayek, R.; Gardner, I. D. Receptor identification. Methods Enzymol. 191:609-639; 1990.

60. Walton, K. M.; Dixon, J. E. Protein tyrosine phosphatases. Annu. Rev. Biochem. 62:101-120; 1993.

61. Wang, H. L.; Bogen, C.; Reisine, T.; Dichter, M. Somatostatin-14 and somatostatin-28 induce opposite effects on potassium currents in rat neocortical neurons. Proc. Natl. Acad. Sci. USA 86:9616$9620 ; 1989$.

62. Wang, H. L.; Reisine, T.; Dichter, M. Somatostatin-14 and somatostatin-28 inhibit calcium currents in rat neocortical neurons. Neuroscience 342:335-342; 1990.

63. Yamada, Y.; Reisine, T.; Law, S. F.; et al. Somatostatin receptors and expanding gene family: Cloning and functional characterization of human SSTR3, a protein coupled to adenylyl cyclase. Mol. Endocrinol. 6:2136-2142; 1992. 